\title{
Antioxidant Effects of Red Fruit Oil on MMP-1 Gene Expression and Malondialdehyde Levels on Skin Exposed to UVB Rays
}

\author{
Monita Sugianto ${ }^{1}$, Achadiyani², Gaga Irawan Nugraha ${ }^{3}$ \\ ${ }^{1}$ Postgraduate Program of Antiaging and Aesthetics Medicine, Faculty of Medicine, Universitas Padjadjaran, Bandung, Indonesia \\ ${ }^{2}$ Physiology Division, Department of Anatomy, Physiology and Cell Biology, Faculty of Medicine, Universitas Padjadjaran, \\ Jatinangor, Indonesia \\ ${ }^{3}$ Department of Biochemistry and Molecular Biology, Faculty of Medicine, Universitas Padjadjaran, Jatinangor, Indonesia
}

Background: Chronic exposure ultraviolet (UV)-B radiation causes reactive oxygen species (ROS) formation. Furthermore, ROS will induce the formation of malondialdehyde and increase matrix metalloproteinase (MMP)-1 expression. One strategy against the free radicals effects is by consuming antioxidants. This study aims to analyze the antioxidants effect of red fruit oil (RFO) on MMP-1 expression and malondialdehyde levels due to exposure to UVB rays.

Materials and Methods: Thirty male Wistar rats were divided into 5 groups. The P0 group was not given treatment, the P1 group was only exposed to UVB light, the P2 group was exposed to UVB light and given $0.5 \mathrm{~mL} / 200 \mathrm{~g}$ body weight (BW) of RFO, the P3 group was exposed to UVB light and given $1 \mathrm{~mL} / 200 \mathrm{~g} B W$ of RFO, and group P4 exposed to UVB rays and given $2 \mathrm{~mL} / 200 \mathrm{~g}$ BW of RFO. Experimental animals would be examined for MMP-1 expression and malondialdehyde level. RFO would be identified with $\beta$-carotene and tocopherol content.

Results: Beta-carotene and tocopherol were detected in RFO. RFO reduced significantly MMP-1 expression $(p<0.05)$ in P2 group (0.73 \pm 1.27$)$, P3 group (0.63 \pm 0.95$)$, P4 group (9.56 \pm 20.97$)$ compared group P1 (48.07 \pm 65.58$)$. However, RFO did not reduce malondialdehyde levels $(p>0.05)$.

Conclusion: Our research demonstrates RFO containing tocopherol and $\beta$-carotene can reduce the MMP-1 expression, but does not affect malondialdehyde levels due to exposure to UVB rays. An effective dose that can reduce malondialdehyde levels and MMP-1 expression is $1 \mathrm{~mL} / 200 \mathrm{~g}$ BW.

Keywords: red fruit oil, antioxidant, skin, MMP-1 expression, malondialdehyde, UVB rays, photoaging

\section{Introduction}

Skin is a reflection of health status and aging in the body. ${ }^{1}$ Aging skin is a combination of intrinsic and extrinsic aging processes. ${ }^{2}$ The intrinsic aging process is a natural process caused by various factors from within the body itself such as genetic, hormonal and racial. While extrinsic aging processes occur due to various external factors, like ultraviolet radiation. ${ }^{3}$ 
Photoaging is the macroscopic, microscopic and functional condition of the skin due to chronic and recurrent exposure of ultraviolet radiation from the sun or artificial light sources. ${ }^{4}$ Chronic exposure ultraviolet (UV)-A and UVB cause the formation of reactive oxygen species (ROS) in keratinocyte cells and papillary fibroblast cells. ${ }^{5}$ ROS cause lipid peroxidation and form lipid hydroperoxide. ${ }^{6}$ The structure of lipid hydroperoxide is very unstable and can easily changes to malondialdehyde, 4-hydroxy-2nonenal (4-HNE ) and other aldehydes thereby increasing the state of oxidative stress. ${ }^{7}$ ROS also induces activation of the transcription factor nuclear factor-kappaB (NF- $\kappa \mathrm{B})$ and activator protein (AP)-1 and damage to the strand of DNA. Induction of AP-1 and NF- $\mathrm{kB}$ promotes collagen breakdown by regulating matrix metalloproteinases (MMPs) expression, including interstitial collagenase/MMP- $1 .{ }^{8}$

Prevention is the best and most effective way to work against the effects of extrinsic skin aging. One strategy to counter the effects of free radicals is by consuming antioxidants. ${ }^{9}$ Red fruit (Pandanus conoideus) is an endemic plant in the Papua region, Indonesia which is reported to be very rich in carotenoids (pro-vitamin A), tocopherol (vitamin E), and unsaturated fatty acids. ${ }^{10}$ Red fruit oil (RFO) contains total phenol 90-742 ppm, total tocopherol 234-1728 ppm, $\alpha$-tocopherol 52-272 ppm, $\gamma$-tocopherol 16-287 ppm. ${ }^{11}$ Carotenoids identified in RFO are $\alpha$-, $\beta$-carotene and $\alpha$-, $\beta$-cryptoxanthin. ${ }^{12}$ Beta-carotene and $\beta$-cryptoxanthin from RFO respectively 123 to $2250 \mathrm{ng} /$ $\mathrm{mg}$ and 5 to $90 \mathrm{ng} / \mathrm{mg} .{ }^{13}$ Variations in reported values may be due to differences in clones and origin of red fruit, and/or analytical methods used.

High antioxidant content in this red fruit makes many researchers are interested to finding its potential. However, research about the potential health benefits of RFO on the skin has never been done. Therefore the researchers' interest to examining the effect of RFO on malondialdehyde levels and MMP-1 expression in the male Wistar rats skin exposed to UVB rays.

\section{Materials and methods}

\section{Preparation of RFO}

RFO is an oil produced by the red fruit extraction process originating from Wamena, Papua. The process is carried out by PT. Prima Solusi Medikal, Jakarta, Indonesia. The human dose of RFO was 2-3 spoons/day/70 kg BW (30-45 $\mathrm{mL} /$ day/70 $\mathrm{kg} \mathrm{BW}$ ). The conversion factor of human to rat dosage was $0.018 .{ }^{14}$ The dose for rat used is $0.5 \mathrm{~mL} / 200 \mathrm{~g}$ $\mathrm{BW}, 1 \mathrm{~mL} / 200 \mathrm{~g} \mathrm{BW}$, and $2 \mathrm{~mL} / 200 \mathrm{~g} \mathrm{BW} .^{15}$

\section{Experimental Animals}

Thirty male rats (Rattus novergicus) Wistar strain with aged 10-12 weeks and had body weight between 150-250 $\mathrm{g}$ were obtained from the animal laboratory PT. Biofarma, Bandung, Indonesia. Then an adaptation was carried out in the laboratory of the Department of Pharmacology, Faculty of Medicine, Padjadjaran University, Bandung, Indonesia for 1 week. Rats were placed in the cages which each contained 3 rats with a temperature (temperature of 20 $25^{\circ} \mathrm{C}$ ) and a cycle of 12 hours of light- 12 hours of darkness.

\section{Phytochemical Screening Assay}

The phytochemical assay was conducted on RFO to qualitatively identify presence of phenolics, flavonoids, steroids, triterpenoids, saponins, tannins, and alkaloids. ${ }^{16}$ Precipitate formation and/or changes in color intensity after addition of certain reagents were observed.

\section{Identification $\beta$-Carotene and Tocopherol by Thin Layer Chromatography (TLC)}

The eluent system used in flash column chromatography was determined first by TLC. Determination of eluent system with TLC was carried out by trial and error method. The mobile phase used was n-hexane and ethyl acetate which varied the level of polarity by varying the volume ratio to obtain the volume ratio that gave the best separation. The RFO sample was placed on the TLC plate then eluted with various variations of the n-hexane: ethyl acetate $(\mathrm{v} / \mathrm{v})$ ratio. The variation consists of a ratio of $n$-hexane $100 \%$, $100 \%$ ethyl acetate, $\mathrm{n}$-hexane acetate. A sample of $1 \mathrm{~g}$ was added to the column and eluted using eluent results from TLC. Then the eluate was accommodated in 54 vials with 2-3 mL eluets per each vial. From each of these vials TLC tests were carried out to determine the separation profile. Fractions that have the price of $\mathrm{Rf}$ identic are combined into one.

\section{Preparation of Photoaging Rats}

The rats were acclimatized for one week before the study. Thirty rats divided into five groups ( $\mathrm{n}=6$ groups of rats). The $\mathrm{P} 0$ group was not given treatment, the $\mathrm{P} 1$ group was only exposed to UVB light, the P2 group was exposed to UVB light and given RFO $0.5 \mathrm{~mL} / 200 \mathrm{~g}$ BW once a day, the $\mathrm{P} 3$ group was exposed to UVB light and was given RFO 
$1 \mathrm{~mL} / 200 \mathrm{~g} \mathrm{BW}$ once a day, and group P4 exposed to UVB rays and given RFO $2 \mathrm{~mL} / 200 \mathrm{~g} \mathrm{BW}$ once a day. The observation time is 10 weeks. This 10 week time interval is determined by the average observation time used by Bhattacaryya ${ }^{17}$, Peres $^{18}$. The skin area located at $5 \mathrm{~cm}$ from the ear was shaved by using a hair shaver every week. Shaving area was $3 \times 3 \mathrm{~cm}$. All procedures were approved by the Ethics Committee, Faculty of Medicine, Padjadjaran University, Bandung (Animal Ethics Number: 1043/UN6. $\mathrm{KEP} / \mathrm{EC} / 2018)$.

\section{UVB Irradiation}

Four groups (P1, P2, P3 and P4) would be given irradiation using UVB lamp (Kernel brand type KN-4003, 0.07 mwatt/ $\mathrm{cm}^{2}$, Shanghai, China). The distance between UVB lamp and the interscapular area was $\pm 3 \mathrm{~cm}$. Radiation was carried out for 30 seconds and 3 times a week for 10 weeks. Radiation dosage used was $130 \mathrm{~mJ} / \mathrm{cm}^{2} .{ }^{17,19,20}$

\section{Skin Sample Collection}

Twenty-four hours after the last UV exposure, skin samples were excised using a sterile scalpel and collected from the $1 \times 2 \mathrm{~cm}$ interscapular region under ketamine anesthesia. Skin samples were divided into 2 parts for thiobarbituric acid reactive substances (TBARS) and real-time polymerase chain reaction (RT-PCR) test.

\section{RNA Extraction and Semiquantitative RT-PCR}

Total RNA from skin was extracted using the TRIzol reagent (Thermo Fisher, Massachusetts, USA) in accordance with the manufacturer's protocol. The RNA was stored at $-80^{\circ} \mathrm{C}$ until it was used. A total of $150 \mathrm{ng}$ RNA and $0.2 \mu \mathrm{M}$ of forward and backward specific primers were added to a mixed One-step RT-PCR kit (MyTaq One step kit RT-PCR, Bioline, Massachusetts, USA), following the manufacturer's protocol. The conditions of the PCR stage were followed: denaturation was $94^{\circ} \mathrm{C}$ for 2 minutes; annealing was $56^{\circ} \mathrm{C}$ for 2 minutes; amplification/extension was $72^{\circ} \mathrm{C}$ for 3 minutes, all of these processes are repeated for 34 cycles. The primers used 5'-TGGGATTTCCAAAAGAAGTG-3 'and 5'-ACGTGGTTCCCTGAGAAGA-3' for MMP$1 ;$ and 5'-TGGAGAAGATTTGGCACC-3' and 5 '-CCAGAGGCATACAGGGACAA-3' for $\beta$-actin. The level of $\beta$-actin as an internal control normalizes the PCR product of each gene that is in demand. All procedures were repeated three times to confirm the consistency of the results.

\section{TBARS Assay}

The skin tissue was weighed $0.2 \mathrm{~g}$ and perfused with cold physiological $\mathrm{NaCl}$ solution. Then the tissue was homogenized to a $20 \%$ homogenate solution with saline. Homogenate solution, sodium dodecyl sulfate (SDS) solution, thiobarbituric acid (TBA) solution, acetic acid, butylated hydroxytoluene (BHT) and ethylenediaminetetraacetic acid (EDTA) solution were mixed well. After the ingredients were mixed, heat in a $100^{\circ} \mathrm{C}$ water bath for 60 minutes. Cool immediately in an ice bath. After that, the mixture will produce pink as a result of the malondialdehyde reaction with TBA. The mixture was centrifuged with a speed of 3000rpm for 10 minutes. The supernatant was measured for its absorbance at a wavelength of $532 \mathrm{~nm}$ using a spectrophotometric device.

\section{Statistical Analysis}

Comparing differences between malondialdehyde levels and MMP-1 gene expression between groups P0, P1, P2, $\mathrm{P} 3$, and P4 carried out data processing. Data was processed and presented using the statistical package for social science (SPSS) version 25 programs (SPSS Inc., Chicago, USA). Data were expressed as mean \pm standard error minimum (SEM). Statistical significant was considered at $p<0.05$.

\section{Results}

\section{Phytochemical Test}

Phytochemical screening showed that RFO contained steroids and triterpenoids (Figure 1 and Table 1).

\section{Identification of $\beta$-carotene and Tocopherol}

There was a spot $(\operatorname{Rf} 0.28$ and 0.85$)$, which is the same in RFO samples with $\beta$-carotene and tocopherol so it was concluded that RFO contains tocopherol and $\beta$-carotene (Figure 2).

\section{RFO Suppresses MMP-1 Expression}

The expression of the MMP-1 gene was examined by semi-quantitative RT-PCR. After normalizing with $\beta$-actin mRNA, the results showed that the relative ratio of MMP1 expression was $2.31 \pm 2.49$ in group $\mathrm{P} 0 ; 48.07 \pm 65.58$ in group P1; 0.73 \pm 1.27 in group P2; $0.63 \pm 0.95$ in the P3 group; and $9.56 \pm 20.97$ in group $\mathrm{P} 4$ (Table 2). The comparison of groups P0 \& P1, P1 \& P2, P1 \& P3, P1 \& P4 was known to have a value of $p<0.05$ so it could be concluded that there was a statistically significant difference in the expression variables of the MMP-1 gene between groups (Figure 3 and 


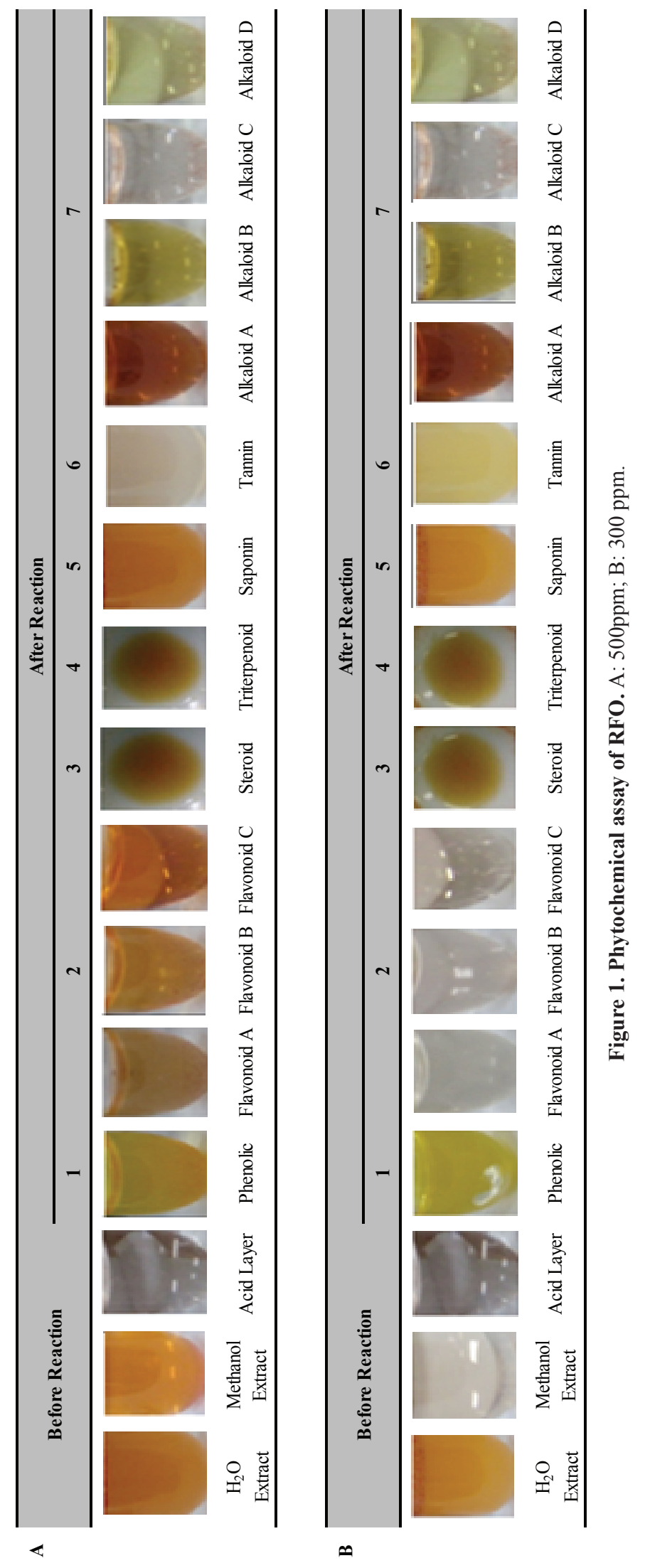


Table 1. Phytochemical assay result. RFO contains steroids and triterpnoids.

\begin{tabular}{lll}
\hline \multicolumn{1}{c}{$\begin{array}{c}\text { Secondary } \\
\text { Metabolites }\end{array}$} & \multicolumn{1}{c}{ Method } & Result \\
\hline Phenolics & $\mathrm{FeCl}_{3} 5 \%$ reagent & - \\
\hline Flavonoids & $\mathrm{HCL}+\mathrm{Mg}$ reagent & - \\
& $\mathrm{H}_{2} \mathrm{SO}_{4} 2 \mathrm{~N}$ reagent & - \\
\hline Steroids & $\mathrm{NaOH} 10 \%$ reagent & - \\
\hline Triterpenoids & Lieberman-burchard & + \\
\hline Saponins & Lieberman-burchard & + \\
\hline Tannins & $\mathrm{HCl}+\mathrm{H}_{2} \mathrm{O}$ reagent & - \\
\hline & $\mathrm{FeCl}_{3} 1 \%$ & - \\
\hline Alkaloids & Dragendorf reagent & - \\
& Wagner reagent & - \\
& Mayer reagent & - \\
\hline
\end{tabular}

Table 2). While the comparison of groups P0 \& P2, P0 \& P3, P0 \& P4, P2 \& P3, P2 \& P4, P3 \& P4 was known to have a value of $p>0.05$ so it can be concluded that there is no statistically significant difference in the expression variables of MMP-1 genes between groups. The P3 group had the lowest MMP-1 gene expression, $0.63 \pm 0.95$. Thus it can be concluded that red fruit oil can suppress the expression of the MMP-1 gene at a dose $1 \mathrm{~mL} / 200 \mathrm{~g} \mathrm{BW}$. But the MMP-1 expression in P4 group increased higher than P2 and P3 group.

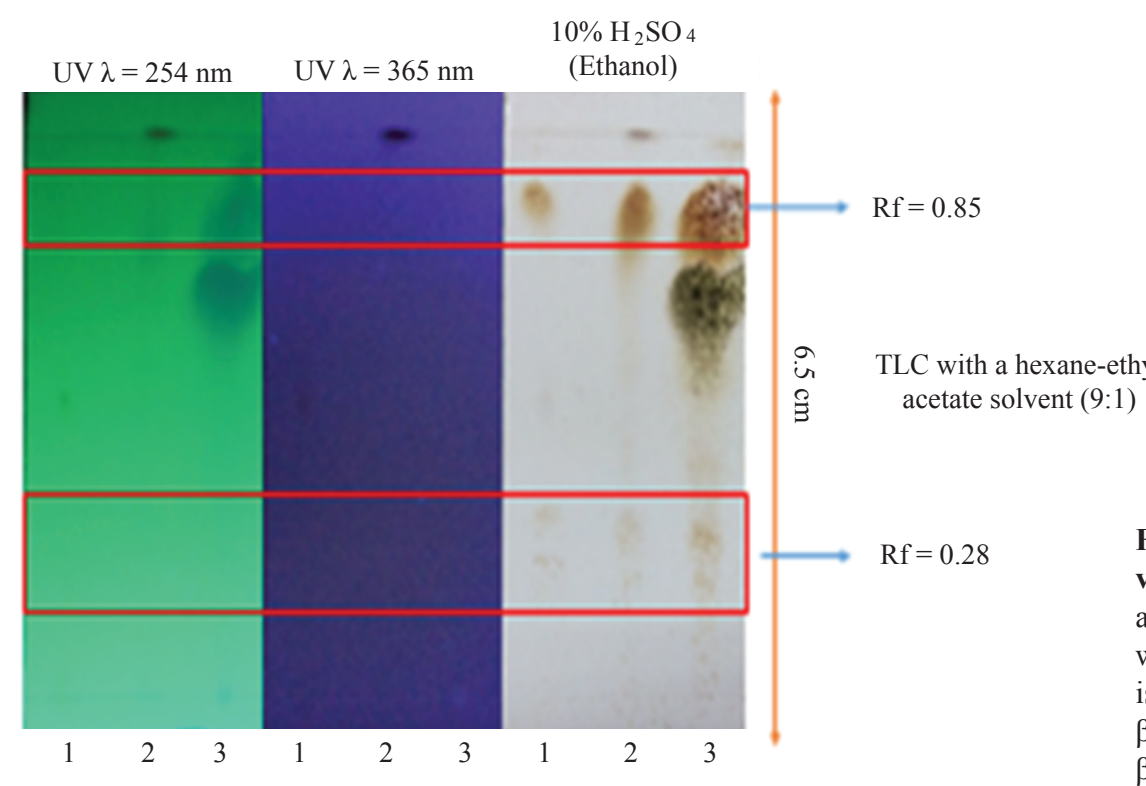

\section{Effect of RFO on Malondialdehyde Levels}

Examination of malondialdehyde levels tested with TBARS results showed average malondialdehyde levels in P0 group 9.08 \pm 3.43 ; P1 group 6.72 \pm 2.77 ; P2 group 7.94 \pm 1.64 ; P3 group 6.62 \pm 1.67 ; P4 group $7.24 \pm 1.75$ (Table 2). Comparison of groups was known that there is no difference in the mean statistically significant malondialdehyde level between groups (Table 2 and Figure 4). Thus it could be concluded that the antioxidant content of RFO did not reduce malondialdehyde levels in P2, P3, and P4 groups. The exposure dose of UVB decreased the levels of malondialdehyde in groups P1, P2, P3 and P4 compared to P0. The P3 group had the lowest MDA levels, 6.6 \pm 1.67 .

\section{Discussion}

Giving antioxidants is one of the management for photoaging. Acute exposure to human skin against UVR causes oxidation of cellular biomolecules which can be prevented by previous antioxidant treatment. ${ }^{21}$ The content of RFO in this study proved to contain $\beta$-carotene and vitamin $\mathrm{E}$ in accordance with previous studies. ${ }^{22}$ In this study, researchers used RFO as an inhibitor of the MMP-1 gene expression and malondialdehyde levels in rat skin due to exposure to UVB rays.

We found that after administering RFO at doses of 0.5 , 1 and $2 \mathrm{~mL} / 200 \mathrm{~g} \mathrm{BW}$, the expression of the MMP-1 gene could be significantly decreased compared to the group exposed to UVB light only. Giving a dose of $2 \mathrm{~mL} / 200 \mathrm{~g}$
Figure 2. Identification of $\beta$-carotene and vitamin $\mathbf{E}$ in RFO. There is a spot ( Rf 0.28 and 0.85) that is the same in RFO samples with $\beta$-carotene and tocopherol so that RFO is expressed containing tocopherol and $\beta$-carotene. 1: Sample of RFO; 2: Standard of $\beta$-carotene; 3: Standard of vitamin E. 
Table 2. Effects of RFO on MMP-1 and malondialdehyde on photoaged mice skin.

\begin{tabular}{|c|c|c|c|c|c|}
\hline \multirow{2}{*}{ Groups } & \multirow{2}{*}{$\mathbf{n}$} & \multicolumn{2}{|c|}{ MMP-1 Expression } & \multicolumn{2}{|c|}{ Malondialdehyde Levels } \\
\hline & & Mean $\pm S D(p g)$ & $p$-value* & Mean $\pm S D(p g)$ & $p$-value* \\
\hline P0 Group & 6 & $2.31 \pm 2.49$ & $0.015^{*}$ & $9.08 \pm 3.43$ & 0.096 \\
\hline P2 Group & 6 & $0.73 \pm 1.27$ & $0.004 *$ & $7.94 \pm 1.64$ & 0.380 \\
\hline P3 Group & 6 & $0.63 \pm 0.95$ & $0.004 *$ & $6.62 \pm 1.67$ & 0.942 \\
\hline P4 Group & 6 & $9.56 \pm 20.97$ & $0.041 *$ & $7.24 \pm 1.75$ & 0.706 \\
\hline
\end{tabular}

BW reduced MMP-1 gene expression less than the group given a dose of 0.5 and $1 \mathrm{~mL} / 200 \mathrm{~g} \mathrm{BW}$. This is because the excess content of $\beta$-carotene and vitamin $\mathrm{E}$ can be prooxidants. Previous studies showed that lower administration of $\beta$-carotene concentrations $(0.02 \mu \mathrm{g} / \mathrm{mL})$ showed a better effect to counteract free radicals than higher $\beta$-carotene concentrations $(0.1 \mu \mathrm{g} / \mathrm{mL})$. Higher concentrations of $\beta$-carotene encourage a shift to the pro-oxidative side with an increase in ROS formation and a decrease in the concentration of Glutathione (GSH). ${ }^{23}$ In this study the levels of malondialdehyde did not decrease with the administration of RFO containing vitamin $E$ and $\beta$-carotene. In a previous study, administration of oral $\alpha$-tocopherol to hairless mice, did not affect malondialdehyde levels but administration of oral $\alpha$-tocopherol protected epidermal DNA damage due to exposure to UVB rays. ${ }^{24}$ Exposure to UVB rays in this study induced free radical formation. The formed free radicals will induce the occurrence of lipid peroxidation, which will produce several products including 4-HNE and MDA. Levels of 4-HNE in moderate concentration will release signals for cell survival. Four-
HNE regulates several transcription factors that will increase when oxidative stress conditions such as Nuclear factor erythroid 2-related factor 2 (Nrf2), activate AP-1, $\mathrm{NF}-\kappa \mathrm{B}$, and peroxisome-proliferator-activated receptors (PPAR). In physiological conditions, Nrf2 is deactivated in the cytoplasm by the Keap 1 repressor protein, but in response to oxidant stimulants, Nrf2 is activated and translocated into the cell nucleus where antioxidant/cytoprotective gene transcription binds antioxidant response elements (ARE) in DNA. Activated Nrf2 will affect malondialdehyde levels by increasing the synthesis of GSH in cells, thereby accelerating the metabolism of MDA. ${ }^{7}$

\section{Conclusion}

RFO containing tocopherol and $\beta$-carotene can reduce the expansion of the MMP-1 gene, but does not affect the formation of malondialdehyde due to exposure to UVB rays. An effective dose that can reduce malondialdehyde levels and the expression of the MMP- 1 gene is $1 \mathrm{~mL} / 200 \mathrm{~g}$ BW. This pre-clinical research on the administration of RFO can be the basis of further clinical research.



Figure 3. Quantification of ratio (normalized by $\beta$-Actin) showing net changes of MMP1 mRNA expression. Bars represent the means of the ratios \pm SEM, $(n=6$, $* p<0.05$ ). 


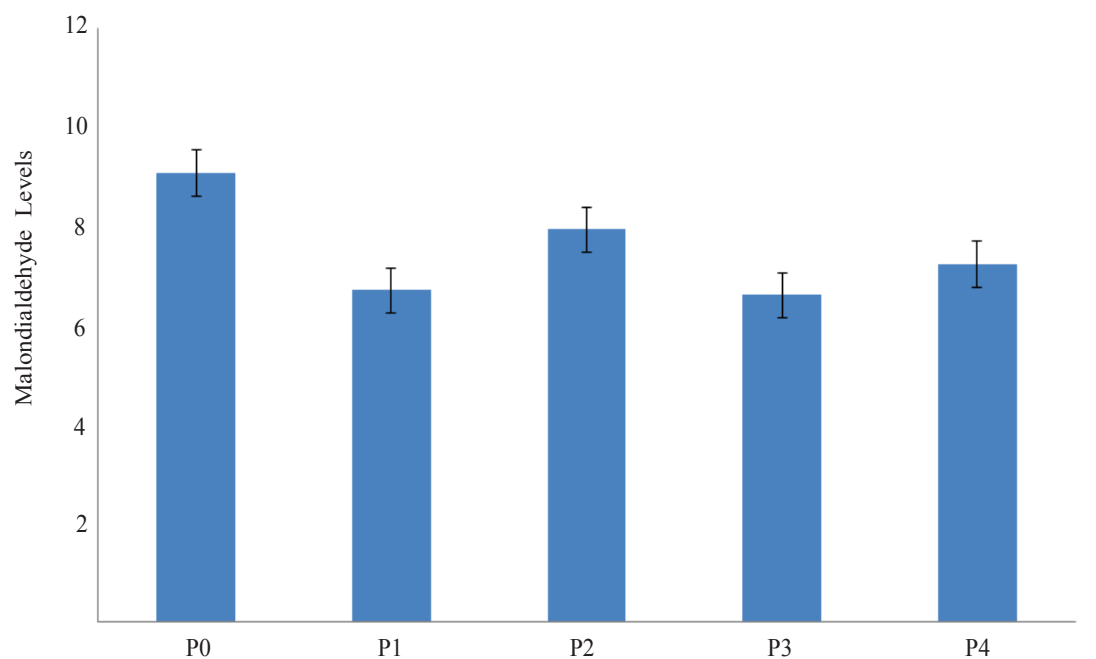

Figure 4. Quantification of Malondialdehyde levels. Bars represent the means of the ratios \pm SEM, $\left(\mathrm{n}=5,{ }^{*} p<0.05\right)$.

\section{References}

1. Schagen SK, Zampeli VA, Makrantonaki E, Zouboulis CC. Discovering the link between nutrition and skin aging. Dermatoendocrinol. 2012; 4(3): 298-307.

2. Tobin DJ. Introduction to skin aging. J Tissue Viability. 2017; 26(1): 37-46.

3. Farage MA, Miller KW, Elsner P, Maibach HI. Intrinsic and extrinsic factors in skin ageing: a review. Int J Cosmet Sci. 2008; 30(2): 8795.

4. Rittié L, Fisher GJ. UV-light-induced signal cascades and skin aging. Ageing Res Rev. 2002; 1(4): 705-20.

5. Brenneisen P, Sies H, Scharffetter-Kochanek K. Ultraviolet-B irradiation and matrix metalloproteinases: from induction via signaling to initial events. Ann NY Acad Sci. 2002; 973: 31-43.

6. Diaconu RE, Macarie AE, Orăsan R. Analysis of oxidative stress in sun-exposed and unexposed skin. Hum Vet Med. 2014; 6(3): 153-7.

7. Ayala A, Muñoz MF, Argüelles S. Lipid peroxidation: production, metabolism, and signaling mechanisms of malondialdehyde and 4-hydroxy-2-nonenal. Oxid Med Cell Longev. 2014; 2014:360438. doi: $10.1155 / 2014 / 360438$.

8. Ciążyńska M, Bednarski IA, Wódz K, Narbutt J, Sobjanek M, Woźniacka A, et al. Impact of ultraviolet radiation on expression of transforming growth factor $\beta$, Smad2, metalloproteinases-1, $-3,-8$, -9 , cathepsin K and progerin. Photochem Photobiol. 2018; 12(10): 3218-21.

9. Karimi K, Lindgren TH, Koch CA, Brodell RT. Obesity as a risk factor for malignant melanoma and non-melanoma skin cancer. Rev Endocr Metab Disord. 2016; 17(3): 389-403.

10. Murtiningrum, Sarungallo ZL, Mawikere NL. The Exploration and diversity of red fruit (Pandanus conoideus L.) from papua based on its physical characteristics and chemical composition. J Biol Divers. 2012; 13(3): 124-9.

11. Sarungallo ZL, Hariyadi P, Andarwulan N, Purnomo EH. Characterization of chemical properties, lipid profile, total phenol and tocopherol content of oils extracted from nine clones of red fruit (Pandanus conoideus). Kasetsart J - Nat Sci. 2015; 49(2): 237-50.

12. Sarungallo ZL, Hariyadi P, Andarwulan N, Purnomo EH, Wada M. Analysis of $\alpha$-Cryptoxanthin, $\beta$-Cryptoxanthin, $\alpha$-Carotene, and $\beta$-Carotene of Pandanus conoideus oil by high-performance liquid chromatography (HPLC). Procedia Food Sci. 2015; 3: 231-43.

13. Rohman A, Sugeng R, Che Man YB. Characterizaton of red fruit (Pandanus conoideus Lam) oil. Int Food Res J. 2012; 19(2): 563-7.
14. Laurence DR, Bacharach AL. Evaluation of Drug Activities: Pharmacometrics. 1st ed. Cambridge: Academic Press Inc; 1964.

15. Munim A, Andrajati R, Susilowati H. Uji hambatan tumorigenesis sari buah merah (Pandanus Conoideus Lam.) terhadap tikus putih betina yang diinduksi 7,12 dimetilbenz(a)antrasen (DMBA). Pharm Sci Res. 2006; 3(3): 153-61.

16. Sumiwi SA, Zuhrotun A, Hendriani R, Rizal M, Levita J, Megantara S. Subchronic toxicity of Ethanol Extract of Syzygium polyanthum (Wight) Walp. Leaves on Wistar Rat. Indones Biomed J. 2018;(3): 9024246. doi: 10.1155/2017/9024246.

17. Bhattacharyya TK, Hsia Y, Weeks DM, Dixon TK, Lepe J, Thomas JR. Association of diet with skin histological features in UV-Bexposed mice. JAMA Facial Plast Surg. 2017; 19(5): 399-405.

18. Peres PS, Terra VA, Guarnier FA, Cecchini R, Cecchini AL. Photoaging and chronological aging profile: understanding oxidation of the skin. J Photochem Photobiol B Biol. 2011; 103(2): 93-7.

19. Hossy BH, Leitão AA da C, Torres RB, Ramos-e-Silva M, Miguel $\mathrm{NC}$ de $\mathrm{O}$, de Pádula M. Histological observation of hairless mice skin after exposure to simulated solar light: comparison between the histological findings with different methodologies and 3R principle correlations. Burns. 2018; 44(2): 359-69.

20. Sofiah AS, Lesmana R, Farenia R, Adi S, Goenawan H, Megantara $\mathrm{I}$, et al. Astaxanthin cream alters type I procollagen and matrix metalloproteinase-1 (MMP-1) gene expression induced by ultraviolet B irradiation in rat skin. J Biomed Clin Sci. 2018; 3: $62-7$.

21. Pandel R, Poljšak B, Godic A, Dahmane R. Skin photoaging and the role of antioxidants in its prevention. ISRN Dermatol. 2013; 2013: $1-11$.

22. Sarungallo ZL, Roreng MK. Kandungan Komponen Aktif Minyak Kasar dan Hasil Degumming dari Buah Merah (Pandanus conoideus) Yang Diekstrak Secara Tradisional. In: Seminar Nasional Persatuan Ahli Ilmu Pangan Indonesia (PATPI). Manado: PATPI: 2011.

23. Lohan SB, Vitt K, Scholz P, Keck CM, Meinke MC. ROS Production and glutathione response in keratinocytes after application of $\beta$-carotene and VIS/NIR irradiation. Chem Biol Interact. 2018; 280: $1-7$.

24. Record IR, Dreosti IE, Konstantinopoulos M, Buckley RA. The influence of topical and systemic vitamin $\mathrm{E}$ on ultraviolet lightinduced skin damage in hairless mice. Nutr Cancer. 1991; 16(3-4): 219-25. 